\title{
Rapeseed meal and urea as a protein source for growing bulls on alkali-treated straw-based feeding
}

\author{
LIISA SYRJÄLÄ-QVIST and MIKKO TUORI \\ Department of Animal Husbandry, University of Helsinki, \\ SF-00710 Helsinki 71
}

\begin{abstract}
Between the ages of $31 / 2$ and 10 months, 12 bulls took part in an experiment in which 1) Tower rapeseed meal or 2) urea plus rapeseed meal was used as a protein source in a diet based on dry alkali-treated straw. In group 1 the rapeseed meal composed $32 \%$ of a concentrate mixture also containing barley, oats, molassed beet pulp and minerals. The average daily consumption of rapeseed meal was $1.2 \mathrm{~kg} /$ animal and it contributed $58 \%$ of the digestible crude protein supply. In group 2 urea composed $2 \%$ of the concentrate mixture and the average daily consumption was $84 \mathrm{~g}$ /animal. In this group urea contributed about $38 \%$ and rapeseed meal $20 \%$ of the digestible crude protein supply. The palatability of the concentrate mixture was good in both groups. The average daily intake of alkalitreated straw was $2.3 \mathrm{~kg} /$ animal or $0.77 \mathrm{~kg}$ dry matter/100 live weight $\mathrm{kg}$. Treated straw was the only roughage received by the animals from the age of 6 months. Up to that age the animals also received hay, on average $840 \mathrm{~g}$ per animal and day.

The average daily live weight gain in group 1 was $1072 \mathrm{~g} /$ animal and in group 2 it was $1111 \mathrm{~g}$; the carcass weights in the respective groups were $169 \mathrm{~kg}$ and $176 \mathrm{~kg}$, and the feed conversion rates were $4.08 \mathrm{f} . \mathrm{u}$. and $4.16 \mathrm{f} . \mathrm{u} . / \mathrm{kg}$ live weight gain. The differences between the group were not significant $(\mathrm{P}>0.05)$.

Almost all the animals showed pathological changes in their inner organs, which may mean that alkali-treated straw sounds not to be suitable as the only roughage source for growing bulls.
\end{abstract}

\section{Introduction}

The use of straw as the only source of roughage for growing bulls has been restricted by its low digestibility and high bulk. It has also been difficult to find an economical domestic source of valuable protein for straw-based feeding in countries like Fin- land, where cultivation is limited by the northern location. The development of methods for improving the energy value of straw and the production of new rapeseed varietes that are low in antinutritional substances and can be cultivated in Finnish conditions as well has now made it possible to start rearing bulls on straw-based feeding. In 
this experiment the feed consumption, growth rate and health of the animals were investigated in bulls receiving alkali straw and rapeseed meal and urea together with grain concentrates.

\section{Experimental procedures}

The experiment was performed with 12 growing male bulls, 10 Ayrshire and 2 Friesian, which were divided by age, live weight and breed into two comparable groups. The animals mean age at the beginning of the experiment was 110 days and their mean weight $140 \mathrm{~kg}$.

The experiment lasted about 7 months, including an adaptation period of three weeks, in which the diet was gradually changed to that of the experimental regime. The experimental diets consisted of alkalitreated straw fed ad libitum, with hay during the first months of the experiment (Fig. 1), and a concentrate mixture consisting of barley, oats, molassed beet pulp and a commercial mineral mixture. As an additional source of protein, one group received rapeseed meal (RSM group) and the other group urea + rapeseed meal (UREA group Table 1).

The bulls were fed individually twice a day at a level which satisfied the energy and protein demands of animals growing at a rate of $1000 \mathrm{~g} /$ day (DAENICKE and RoHr 1974). They

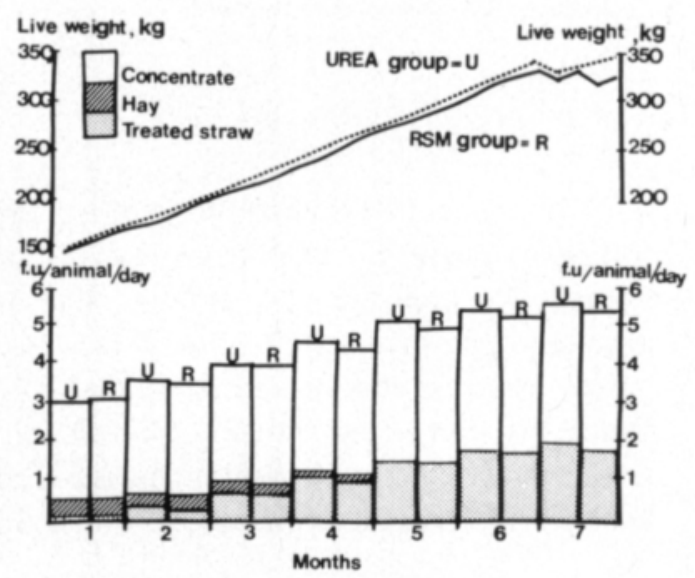

Fig. 1. Live weight gain and feed consumption in different groups.
Table 1. Average percentages of different components in the concentrate mixture during the experiment.

\begin{tabular}{lcc}
\hline Groups & RSM & UREA \\
\hline Barley & 27.5 & 37 \\
Oats & 27.5 & 37 \\
Molassed beet pulp & 10 & 10 \\
Rapeseed meal & 32 & 11 \\
Urea & - & 2 \\
Minerals & 3 & 3 \\
kg/f.u. & 1.14 & 1.12 \\
DCP, g/f.u. & 171 & 170 \\
\hline
\end{tabular}

f.u. $=$ feed unit $=0.7$ starch equivalent

DCP $=$ digestible crude protein

were weighed on two days at the beginning of the experiment and once a week during the experiment. The quantities of grain and the protein sources were adjusted as the weights increased, using weight intervals of $20 \mathrm{~kg}$.

The rapeseed meal used in the experiment was the Tower variety, in which the content of glucosinolates was only $0.2 \%$ of dry matter and that of tannins $1.3 \%$.

The straw was mainly wheat straw. It was dry alkali-treated with a mobile machine (JF SP2000), in which the straw is chopped, and alkali solution added and mixed with the straw. The amount of $\mathrm{NaOH}$ added was $4.3 \%$ of the dry matter of the straw. The unreacted base was determined by titration to $\mathrm{pH} 8$ with $0.1 \mathrm{HCl}$. The residual $\mathrm{NaOH}$ averaged $0.96 \%$ of the dry matter.

The chemical analyses of the feeds were made by standard procedures. The feeding values of the concentrates and hay were calculated from the digestibility coefficients obtained from NJF Tables (ANON. 1969, Table 2), but the value for the treated straw was calculated from the results of a digestibility trial performed with adult rams. The digestibility coefficients of the different constituents of the treated straw were as follows: organic matter $70 \%$, crude protein $20 \%$, crude fat $50 \%$, crude fibre $85 \%$ and $\mathrm{N}$-free extract $60 \%$. The value number used cal- 
Table 2. The mean chemical composition and feeding value of the feeds.

\begin{tabular}{|c|c|c|c|c|c|c|}
\hline & $\begin{array}{c}\text { Rapeseed } \\
\text { meal }\end{array}$ & Barley & Oats & $\begin{array}{l}\text { Molassed } \\
\text { beet pulp }\end{array}$ & Hay & $\begin{array}{l}\text { Alkali- } \\
\text { treated } \\
\text { straw }\end{array}$ \\
\hline $\begin{array}{l}\text { Dry matter, } \% \\
\% \text { of DM }\end{array}$ & 87.1 & 89.0 & 88.8 & 87.8 & 86.2 & 78.5 \\
\hline Ash & 8.0 & 2.8 & 3.1 & 9.4 & 6.6 & 10.1 \\
\hline Crude protein & 40.2 & 12.9 & 13.7 & 13.3 & 8.5 & 4.5 \\
\hline Crude fat & 2.2 & 2.4 & 6.2 & 0.5 & 2.0 . & 0.8 \\
\hline Crude fibre & 13.3 & 5.4 & 11.2 & 15.8 & 35.7 & 44.6 \\
\hline $\mathrm{N}$-free extract & 36.3 & 76.5 & 65.8 & 61.0 & 47.2 & 40.0 \\
\hline $\mathrm{kg} /$ f.u. & 1.25 & 0.97 & 1.10 & 1.19 & 2.60 & 2.17 \\
\hline DCP, g/f.u. & 363 & 83 & 104 & 91 & 92 & 20 \\
\hline
\end{tabular}

culating the net energy value (fattening feed unit) was 63 (ANON. 1969).

\section{Results and discussion}

Feed intake and growth rate

The alkali treatment improved the feeding value of the straw. The amount needed for a feed unit was about $2.2 \mathrm{~kg}$, or less than for hay (Table 2). The amount of untreated straw generally needed for a feed unit is 5.5-6.0 kg (ANON. 1969). On average the bulls consumed $2.3 \mathrm{~kg}$ (variation 1.8$3.1 \mathrm{~kg}$ ) straw per day, or $0.77 \mathrm{~kg} \mathrm{DM} / 100 \mathrm{~kg}$ live weight. The contribution of straw to the total DM intake in the UREA and RSM groups was 34 and $33 \%$, respectively. The intake of treated straw varied widely between the animals. Similar intakes of alkali-treated straw have been obtained in other experiments with growing bulls (ARNASON 1980).

After 6 months of age, the treated straw was the only roughage given to the bulls. The daily intake of straw was then $4.3 \mathrm{~kg}$ / animal. Between the age of 3 and 6 months they also consumed hay, the average daily amount being $840 \mathrm{~g} /$ animal.

In the RSM group, the concentrate mixture contained $32 \%$ rapeseed meal (Table 1). Although this proportion of rapeseed meal was about twice as high as is generally recommended (SYRJÄLÄ-QviST et al. 1982) the palatability of the concentrate mixture was good. The daily amount of rapeseed meal consumed by the animals was $1.2 \mathrm{~kg}$ and this supplied about $58 \%$ of their digestible crude protein.

In the UREA group, the mean consumption of rapeseed meal was $400 \mathrm{~g}$ per animal and day and that of urea $84 \mathrm{~g} /$ day, the maximal amounts of urea being $40 \mathrm{~g} / 100$ live weight $\mathrm{kg}$. In this group the bulls received about $38 \%$ of their digestible crude protein from urea and $20 \%$ from rapeseed meal. The palatability of the concentrate mixture was good in this group also.

In the RSM group the roughage/concentrate ratio, calculated from the dry matter,

Table 3. Live weight gain, feed consumption and slaughter results.

\begin{tabular}{lcc}
\hline Groups & RSM & UREA \\
\hline Initial live weight, kg & 140 & 141 \\
Final live weight, kg & 347 & 356 \\
Live weight gain, g/day & 1072 & 1111 \\
DM supply, kg/day & 5.4 & 5.5 \\
Energy supply, f.u./day & 4.4 & 4.5 \\
DCP supply, g/day & 583 & 582 \\
DCP, g/f.u. & 132 & 134 \\
Feed conversion rate, & & \\
f.u./kg gain & 4.16 & 4.08 \\
Carcass weight, kg & 169 & 176 \\
Dressing, \% & 48.9 & 49.4 \\
\hline
\end{tabular}


was $39 / 61$ and in the UREA group it was $40 / 60$. This can regarded as reaching the optimal level (McCullough 1969).

The live weight gain was even and similar in the two groups; it was somewhat higher in the UREA group, but the difference was not significant $(\mathrm{P}>0.05)$ (Fig. 1, Table 3). The feed conversion rate was also similar in the two groups, or on average $4.1 \mathrm{f} . \mathrm{u} . / \mathrm{kg}$ live weight gain.

\section{Slaughter results and the health of the animals}

By the age of 10 months all the animals had reached a carcass weight of at least $160 \mathrm{~kg}$. In the RSM group it varied from 161 to $183 \mathrm{~kg}$ and in the UREA group from 163

\section{References}

ANON. 1969. Fodermiddeltable. Nord.Jordbr. forskeenes Fören. Gjøvik, 40 p.

Arnason, J. 1980. Torrlutet $(\mathrm{NaOH})$ halm som för til slakteokser. Norges Landbrukshøgskole. Institut for husdyrernăhring. Melding Nr. 204.

Daenicker, R. \& Rohr, K. 1974. Rindermast. Land- und Haus-wirtschaftlicher Auswertungs und Informationsdienst. Bonn-Bad Godesberg. Nr. 372, 19 p. to $181 \mathrm{~kg}$. The dressing $\%$ in both groups averaged $49 \%$.

After slaughter, irritation of the mucous membrane of the small intestine was noted in all the animals; one animal had a liver abscess and there were three cases of inflammation of the kidneys. It has been reported from Norway that bulls fed on $4.7 \mathrm{~kg} \mathrm{DM}$ (= $69 \%$ of total DM) of dry alkali-treated straw had heavier kidneys than bulls fed on untreated straw. In addition, after 12 weeks of feeding treated straw diarrhoea occurred and growth was retarded (ARNASON 1980). According to our results, dry alkali-treated straw cannot be fed ad libitum as the only roughage for growing bulls.

Acknowledgements. - We wish to express our best thanks to Mr. Markku Nieminen for the technical assistance throughout the experiment.

McCullough, M. E. 1969. Optimum feeding of dairy animals. Univ. of Georgia Press, Athens. 180 p.

Syrjälä-Qvist, L., Tuori, M. \& Setälā, J. 1982. Rapeseed meal as a protein source for high-production dairy cows on grass silage- and hay-based feeding. J. Scient.Agric.Soc.Finl. 54: 145-153.

Ms received April 12, 1984 


\section{SELOSTUS}

\section{Rapsirouhe ja urea kasvavan lihanaudan valkuaisen lähteenä lipeäolkiruokinnalla}

\section{Liisa Syrjälä-Qvist ja Mikko Tuori}

Helsingin yliopiston, kotieläintieteen laitos, 00710 Helsinki 71

Koe tehtiin 12 mullilla ikävălillă $31 / 2-10$ kk. Valkuaisen lăhteenă oli toisessa ryhmăssă Tower rapsirouhe ja toisessa urea + rapsirouhe. Rapsirouheen osuus edellisessă ryhmăssă oli $32 \%$ văkirehuseoksessa, joka sisălsi myős ohraa, kauraa ja melassileikettä. Rapsirouheen saantimäărăt olivat keskimäărin $1.2 \mathrm{~kg} /$ eläin/pv ja se korvasi noin $58 \%$ eläimen saamasta sulavasta raakavalkuaisesta. Ureaa sisăltăvăssă ryhmässă ureaa oli $2 \%$ văkirehuseoksessa ja keskimäăräinen annostus $84 \mathrm{~g} /$ elăin/pv. Urea korvasi noin $38 \%$ sulavasta raakavalkuaisesta. Rapsirouhetta eläimet saivat tăssá ryhmässă keskimäărin $400 \mathrm{~g} /$ elăin/pv eli $20 \%$ sulavasta raakavalkuaisesta. Väkirehuseoksen maittavuus oli molemmissa ryhmissă hyvă.

Lipeăolkea eläimet sőivăt keskimäărin $2.3 \mathrm{~kg} / \mathrm{pv}$ eli $0.77 \mathrm{~kg}$ kuiva-ainetta/100 elopainokiloa. Elăinten vălil- lä oli yksilöllisiă eroja oljen syőnnissä. Heinăă mullit saivat puolen vuoden ikäăn asti keskimäărin $840 \mathrm{~g} /$ elăin/pv, mutta tămăn jälkeen lipeăolki oli ainoana karkearehuna.

Elăinten kasvu oli tasaista eikă ryhmien vălillă ollut merkitseviă eroja, joskin ureaa saaneet eläimet kasvoivat hieman paremmin kuin rapsiryhmän eläimet, keskimäărăisten păivăkasvujen ollessa vastaavasti $1111 \mathrm{~g}$ ja $1072 \mathrm{~g}$ sekă teuraspainojen $10 \mathrm{kk}: \mathrm{n}$ iăssă $176 \mathrm{~kg}$ ja $169 \mathrm{~kg}$. Rehua kului molemmissa ryhmissă keskimăărin 4.1 ry/lisăkasvukilo.

Kaikilla eläimillă oli ohutsuolen limakalvo ärtynyt. Yhdellă elăimellă oli mătăpesăke maksassa ja kolmella munuaistulehdus. Tămă antaa aiheen epăillă lipeăoljen soveltuvuutta ainoaksi karkearehuksi. 